\title{
STAGE LEFT AND RIGHT: MODELING CIVIL DISCOURSE IN THE CLASSROOM THROUGH FICTIONAL PRESIDENTIAL DEBATES BETWEEN FDR AND REAGAN
}

\author{
Mark Boulton \\ Westminster College \\ Tobias T. Gibson \\ Westminster College \\ Teaching History 46(2) \\ DOI: 10.33043/TH.46.2.3-11 \\ (C) 2021 Boulton \& Gibson. \\ Distributed with CC BY-NC-ND 4.0 License.
}

As previous eras of social unrest and political upheaval have demonstrated, a polarized body politic is far from being a new phenomenon in U.S. history. However, the resurgent populism of the early twenty-first century, fueled by the information bubbles and feedback loops of social media and an increasingly partisan press, is driving the nation toward evermore dangerous levels of rancor. Insults, violent rhetoric, and misinformation are present in all levels of government. A 2019 Pew Research Center poll found that a significant majority of Americans considered that political debate had become "more negative in recent years [85\%] ... less respectful [85\%], less fact-based [76\%] and less substantive [60\%]." Half of the respondents argued that discussing politics with anyone with an opposing viewpoint had become "stressful and frustrating." The dominance of the twoparty system exacerbates the tribal nature of this division whereby, "Race, religion and ideology now align with partisan identity in ways that they often didn't in eras when the two parties were relatively heterogenous coalitions." The consequences of this acrimony go far beyond the familial strife of an awkward Thanksgiving dinner conversation.

Increasing numbers of Americans now believe that those who do not share their beliefs pose an existential threat to the nation. Stripped of a unifying external danger such as that once posed by global communism, the new enemy is internal: It is fellow Americans. One month before the 2020 presidential election, a poll of over 10,000 registered voters revealed that $90 \%$ of challenger Joseph R. Biden's supporters and $89 \%$ of incumbent Donald Trump supporters believed that the election of the opposing candidate "would lead to lasting harm to the nation."3 These divisions threaten to undermine any sense of a common identity or unifying core value system and, if left unchecked, the consequences on the nation's future could be dire. Higher education has an essential role to play in arresting this decline.

Colleges and universities have the opportunity to nurture informed citizens capable of rational dialogue and empathy to opposing viewpoints. Classroom and extracurricular activities can model respectful political conversation in a way that can bridge the expanding chasms in our society. That is the goal of a class we teach at Westminster College titled, "FDR and Reagan: What the Greatest Presidential Debate in History Can Teach Us About American Politics ... and How We Can All Get Along." The course-which we have now taught twiceuses the speeches and writings of Franklin D. Roosevelt and Ronald Reagan as the basis for students to perform a series of fictional presidential debates between these two giants of American politics. This approach allows students to conduct deep research on each president and to immerse themselves fully in each president's vision for the nation. By inhabiting the character of each leader, they are able to understand the value of political compromise, purposeful bipartisanship, and rhetoric that can both persuade and inspire. As civic educators, our primary purpose with this project is to illustrate and model to our students that respectful political discourse is both possible and essential for the vitality of the republic.

FDR and Reagan inadvertently laid the foundations for the modern acrimonious debates between liberals and conservatives. Following his election in 1932, FDR's New Deal response to the Great Depression created the blueprint for an activist federal government. His contemporary supporters and most modern-day liberals accept

\footnotetext{
1 "Public Highly Critical of State of Political Discourse in the U.S.,"https://www.pewresearch.org/politics/2019/06/19/publichighly-critical-of-state-of-political-discourse-in-the-u-s/

${ }^{2}$ Michael Dimock and Richard Wike, "America is Exceptional in the Nature of its Political Divide," https://www.pewresearch.org/ fact-tank/2020/11/13/america-is-exceptional-in-the-nature-of-its-political-divide/

${ }^{3}$ Ibid.
} 
and encourage the government to intervene and manage society in order to correct social and economic ills. When Ronald Reagan was elected in 1980, he sought to arrest and ultimately reverse the growth of government by cutting taxation and regulation and devolving power back to state and local authorities. His maxim that "The nine most terrifying words in the English language are: I'm from the Government, and I'm here to help" remains a mantra of modern conservatism. ${ }^{4}$ Both are considered transformative presidents because they used moments of crisis - the Depression in the 1930s, the economic downturns and societal malaise of the 1970s-to fundamentally alter the political course of the nation.

Despite their divergent political views, both FDR and Reagan were able to persuade the American electorate that their vision represented the best path forward for the nation. Their election victories-especially for their second terms-were among the largest in the twentieth century: FDR won fifty-seven percent of the popular vote in 1932, sixty-one percent in 1936, fifty-five percent in 1940, and fifty-three percent in 1944; Reagan won fifty-one percent of the popular vote in 1980 and fifty-nine percent in 1984. Both used calm and reassuring rhetoric to convince the public of their vision. Both had their detractors, but FDR's speeches and Fireside Chats and the words which earned Reagan the moniker of "The Great Communicator" modeled how a president can persuade political opponents in a way that was both hopeful and inclusive. Getting our students to inhabit this world is a step toward encouraging them to emulate it.

The dual methods of role-playing and debate offered by our FDR and Reagan course provide a highly effective active-learning mode of instruction. While students often "see themselves as empty buckets being filled with data by their professors," the sage-on-the-stage method of teaching is long outdated. ${ }^{5}$ Multiple studies show the greater effectiveness of creative learning options such as debate, role-playing, group work, and simulations, in addition to varied forms of content delivery such as flipped classrooms. The Model Arab League, for example, puts students "in the shoes of real-life Arab diplomats and other foreign affairs practitioners" so that "students come to realize unavoidably and inevitably how different these realities of international relations are in comparison to what they previously thought and wrongly assumed to be true." 6 The critical analysis provided by such methods, rather than mere knowledge accumulation, enhances retention as well as interest in the subject matter. ${ }^{7}$

\section{Examples of Creative Learning in History Classrooms}

To expand on one example of role-playing, John Fliter, at Kansas State University, requires an analysis paper that scrutinizes a Supreme Court justice and his or her jurisprudence. This paper then forms the basis for a student portraying that justice during a case. Fliter assigns foundational readings which discuss the importance and manner of oral arguments on the Supreme Court. Students who serve as the "lawyers" for the oral argument simulation are responsible for preparing a brief, based on real examples of legal briefs, in time to allow the justices to prepare for a performed oral argument. The oral arguments take place in a special room, not the regular classroom, as Fliter discovered that his students are "more engaged and enthusiastic" when the arguments are held outside of the class's regular confines.

Importantly, rather than following the usual model of the Supreme Court, Fliter requires all members

\footnotetext{
${ }^{4}$ Ronald Reagan, "Reagan Quotes and Speeches," August 12, 1986, Ronald Reagan Presidential Foundation and Institute, https:// www.reaganfoundation.org/ronald-reagan/reagan-quotes-speeches/news-conference-1/

${ }^{5}$ John C. Bean, Engaging Ideas: The Professor's Guide to Integrating Writing, Critical Thinking, and Active Learning in the Classroom (San Francisco: Jossey-Bass: 2001), 18.

6"About the Program,” Model Arab League, https://ncusar.org/modelarableague/about-model-arab-league/about/

${ }^{7}$ John Fliter, "Incorporating a Sophisticated Supreme Court Simulation into an Undergraduate Constitutional Law Class," Journal of Political Science Education 5, no. 1 (2009): 12-26; Susan Engel, Josh Pallas, and Sarah Lambert, "Model United Nations and Deep Learning: Theoretical and Professional Learning," Journal of Political Science Education 13, no. 2 (2017): 171-184; Stephen R. Bates and Laura Jenkins, "Teaching and Learning Ontology and Epistemology in Political Science," Politics 27, no. 1 (2007): 55-63; Jamie L. Jensen, Tyler A. Kummer, and Patricia D. d. M. Godoy, "Improvements from a Flipped Classroom May Simply Be the Fruits of Active Learning," CBE-Life Sciences Education 14, no. 1 (March 2015): 1-12.
} 
of the "court" to write an opinion following oral arguments. They "are encouraged to find and read several real Supreme Court opinions in order to get a sense of the structure and style of Court opinions." It is clear, then, that although the oral argument is the cornerstone of the class, a great deal of preparation prior to the presentation is necessary, and each student "justice" is required to produce a document after the student lawyers have (literally) made their best case. The active-learning methods discussed above afforded students the benefits of deep learning through iterative, active, and interactive learning projects.

Jeffrey Lantis and others have written on the efficacy of student debates as a method of providing students with "a deeper understanding of (and empathy for) ... ethical complexities." In his analysis of his students' foreign policy debates, he reports "a discernable shift ... toward a more nuanced understanding of the advantages and disadvantages" of complex policy choices. Structured debate, he notes, requires "students to define and defend policy positions that are assigned in advance. In this way, debates demand a level of personal engagement in the process, a measure of group collaboration on debate points, and a willingness to participate in a critical dialogue with the larger group about theoretically significant policy questions." ${ }^{10}$

Our classroom debates are over complex policy spaces-but are also intended to ask students "to walk a mile" in the shoes of political party ideologues with which they may not identify. As will be illustrated below, at minimum, the debate structure diminished the negative stereotyping of the political "other" in our students. This is not a surprising outcome, because previous literature suggests that when students debate positions contrary to their preferences, they can-and often do-change their mind. ${ }^{11}$ This is the kind of learning experience we sought for our students in the FDR and Reagan class.

\section{Classroom Context and Implementation}

Westminster College is a small liberal arts college with relatively small class sizes and an engaged student body. While this environment certainly provides a fertile ground for teaching a class in this method, we believe the model is widely applicable. We first taught the class in the spring of 2018 with ten students as part of our Honors Program curriculum. This is an important point, because while these students were highly motivated, hard-working, and intelligent, only one was a Political Science or History major. Thus, while most of our college's students are not knowledgeable about either FDR or Reagan, our starting point with this class was behind that of the average student in our major classes. The second iteration taught in the spring of 2019 had twenty-two students, mostly juniors and seniors and with a majority being Political Science and History majors. Thus, the second class was advantaged in that each student was much more versed in the nuances of politics, policy, and historical development. We followed the same approximate model of instruction for both classes, with some ameliorations to accommodate the different class sizes and different base knowledge levels.

To begin each class, we gave the students an overview of the historical importance of FDR and Reagan interspersed with short film clips of each president's speeches. This got them engaged with and interested in the style and substance of FDR and Reagan's leadership. Then we asked students to write up some of the negative stereotypes about liberalism and conservatism on the whiteboard. We emphasized that we did not want their opinions but wanted to analyze what is out there in the darker recesses of social media. We had the predictableand all too depressing - results of liberalism being "soft on crime," "godless," "leeches," "America hating," "lazy," "entitled," and "elitist." Conservatives were "greedy," "racist," "anti-science," "homophobic," and "rural." When we asked about the positive sides of each, these negative stereotypes were flipped so, for example, conservatives "love America," "love God," and "love freedom," while liberals were "tolerant," "more rational," and "compassionate."

\footnotetext{
${ }^{8}$ Fliter, "Supreme Court Simulation," 18-19.

${ }^{9}$ Jeffrey S. Lantis, "Ethics and Foreign Policy: Structured Debates for the International Studies Classroom," International Studies Perspectives 5 (2004), 117-133; 128.

${ }^{10}$ Ibid., 122.

${ }^{11}$ Ruth Kennedy, "In-Class Debates: Fertile Ground for Active Learning and the Cultivation of Critical Thinking and Oral Communication Skills," International Journal of Teaching and Learning in Higher Education 19, no. 2 (2007): 183-190.
} 
We believe it was important to air these views so that we could find a way to move beyond them. We began this process by collectively analyzing a set of common readings.

We began with some introductory readings on the nature of liberalism and conservatism. The Encyclopedia Britannica entries on the subjects were effective and available online. ${ }^{12}$ These readings allowed us to establish a framework from which students were encouraged to understand that both philosophies want what is best for the nation, they just seek different paths to achieving it. This attempt at promoting empathy for diverse viewpoints was the first step toward mutual understanding. We then moved on to short, easy-to-read biographies on each president as a way to explore how each man embodied liberal and conservative principles. In the first iteration of the class, we read Roy Jenkins's biography, Franklin Delano Roosevelt and then Jacob Weisberg's Ronald Reagan from Times Books' American Presidents series. ${ }^{13}$ The hope was that these short (both under 200 pages), accessible books would provide nearly equal treatment on each subject. Weisberg's is an excellent text; however, both of us, and most of the students, found Jenkins's treatment of FDR to be underwhelming.

Thus, in the second iteration of the class, we changed to the Bedford Series in History and Culture, with Richard Polenberg's The Era of Franklin Delano Roosevelt and Meg Jacobs and Julian Zelizer's Conservatives in Power: The Reagan Years, 1981-1989. ${ }^{14}$ These works served our purposes better for three reasons: First, they offered detailed, but brief, biographies of the presidents (under 50 pages); second, they were of similar quality, which means that the students did not favor one president over the other based on the quality of the text; third, and importantly, both books included pivotal primary sources, including candidate and presidential speeches, allied politicians in the executive and legislative branches, contemporary criticisms and critiques, and first-hand accounts of the successes and failures of policy implementation for both presidents. In short, we found that these books served as richer and more detailed introductions into the subjects of the debates.

With this foundational knowledge, we examined the more densely academic FDR and Reagan: Transformative Presidents with Clashing Visions, by John Sloan. ${ }^{15}$ Sloan superbly details theories of presidential power using Stephen Skowronek's well-respected model of presidential power. This model focuses largely on the political environment, or where a presidency exists, in a political cycle. Sloan makes a strong argument throughout that both FDR and Reagan were transformative presidents which, by highlighting their historical importance and influence, aligns nicely with one of our reasons for teaching this class. One of the points of distinction for Sloan is that he does an excellent job of comparing the presidents side-by-side. Both share a biographical chapter, and then, for example, presidential advisors and "core policies" are compared in back-to-back chapters.

In the second iteration of the class, we added Richard Neustadt's Presidential Power and the Modern Presidents: The Politics of Leadership from Roosevelt to Reagan. ${ }^{16}$ This book was more appropriate for the upper-level course rather than the introductory one because it is quite nuanced, and students at the upper-level are expected to handle a higher reading load. We quickly discovered two advantages of including this textbook. First, it offered a competitor to Skowronek (via Sloan), which allowed the students to debate the merits of the concepts of political time and transformative presidents. Furthermore, Neustadt's timeframe bookends FDR and Reagan; but unlike Sloan, it also discusses the evolution of the modern presidency. This provided necessary historical context to students wondering about development of the executive branch, for example, between 1946 and 1981.

Having established a base knowledge of liberalism and conservatism and of both presidents, in addition

\footnotetext{
12 “Conservatism," Encyclopedia Britannica online, https://www.britannica.com/topic/conservatism; "Liberalism," Encyclopedia Britannica online, https://www.britannica.com/topic/liberalism

${ }^{13}$ Roy Jenkins, Franklin Delano Roosevelt: The American Presidents Series: The 32nd President, 1933-1945 (New York: Times Books, 2003); Jacob Weisberg, Ronald Reagan: The American Presidents Series: The 40th President, 1981-1989 (New York: Times Books, 2016).

${ }^{14}$ Richard Polenberg, The Era of Franklin Delano Roosevelt (Boston: Bedford/St. Martin's, 2000); Meg Jacobs and Julian Zelizer, Conservatives in Power: The Reagan Years, 1981-1989 (Boston: Bedford/St. Martin's, 2010).

${ }^{15}$ John Sloan, FDR and Reagan: Transformative Presidents with Clashing Visions (Lawrence: University Press of Kansas, 2008).

${ }^{16}$ Richard Neustadt, Presidential Power and the Modern Presidents: The Politics of Leadership from Roosevelt to Reagan, Revised edition (New York: Free Press, 1991).
} 
to the nature of presidential power, we engaged students in the process of understanding presidential debates. We read several chapters from Alan Schroeder's Presidential Debates: Risky Business on the Campaign Trail to understand the nature, scope, and format of past debates. ${ }^{17}$ We then broke students up into groups and assigned them a specific presidential debate to watch and analyze. The debates were available on YouTube, and so students analyzed JFK/Nixon, Carter/Reagan, George H.W. Bush/Clinton/Perot, Obama/Romney, and Trump/Clinton. We required each group report back to the class (for about ten minutes) on what they learned about the style and content of their assigned debate. In addition, based on the debate they watched, each group was required to submit five to seven questions the group would have asked had they been moderator.

By watching presidential debates, our students came to appreciate and understand the different styles (single moderator, panel, town hall) and to note how some candidates' performances differed depending on the style of debate. For example, George H.W. Bush famously appeared distant and uninterested in a town hall style debate, while "everyman" Bill Clinton was much more at ease with the public. In addition, by studying different questions asked by different types of questioners-professional journalists versus the famous "undecided voters" of the town hall-the students were also able to model questions for their different styles of debates. Thus, the students were thinking about how to frame a debate and how to make it substantive as part of their building toward performing their own debates.

We assessed the students' knowledge in several ways up to this point in the course. We employed the flipped classroom model of discussion based on readings they had done in advance. We asked students to keep weekly journals in which they took notes on all the assigned materials before class and then took notes of the main points raised by our class discussions. They also had to write two discussion questions for every class in their journals. This held them accountable for doing the reading and gave us license to call on them during class to offer either their thoughts or to prompt them to ask their discussion question. We collected and graded these on a regular basis. Exams could have worked for assessing content knowledge, but we preferred a more Socratic model in order to draw students out of their shells.

The most important components of our class were the presidential debates which allowed our students to inhabit the personalities of FDR and Reagan. Following Fliter and others' leads, we required iterative assignments designed to offer the students several opportunities to inhabit the personas of each president. At the end of the semester, each debate was performed in the largest classroom on campus, and both campus and local media were invited to view and report on the debates. Knowing early in the semester the format and context for the debates indicated to the students, in both classes, that we took the final product very seriously.

Planning for the debate took up the final third of the course. In keeping with historical presidential debates, we chose three topics: Economic Policy, Social Policy, and Foreign Policy. We spent one class period generating debate questions based upon a combination of questions from past presidential debates and questions that we thought would get the best answers out of each candidate. We then had to appoint students to play our FDRs and Reagans. Because our first class contained ten students and our second twenty-two, we approached these debates differently.

There were a lot of commonalities between the two courses, but we had to alter the format and assignments depending on class size. In the ten-student class we prepared three debates of thirty-minutes on each subject. This format provided only six opportunities for students to perform as a presidential candidate. This was not a problem because several students were very enthusiastic about the role-playing, while others were mortified at the thought. Therefore, there was some good-natured negotiation as to who would perform as the presidents. Some students needed to be encouraged, but eventually, we got our six. Three of the remaining students acted as debate moderators. The fourth was responsible for liaising with the campus press and getting word out to the campus community through social media.

\footnotetext{
${ }^{17}$ Alan Schroeder, Presidential Debates: Risky Business on the Campaign Trail, Third edition (New York: Columbia University Press,
} 2016). 
With each student assigned a role, we then broke students down into groups of three, three, and four. Each group acted as a research and prep team responsible for going out and finding speeches and primary source documents for their assigned president and on their assigned topic. We decided collectively that students would know the questions in advance and would have a pre-prepared script to read off in answering the question. This alleviated students' fears of freezing on stage. We agreed that they could go off script in response to their opponent's answer in the rebuttal section, but there was no expectation that they would have to engage in rigorous debate beyond what was written for them.

We gave students two weeks to find sources and come up with their scripted answers. They knew the debate questions, now they had to find the words from each president on how they would have answered. It was essential that primary sources from each the president's speeches and writings formed the basis of the debate content: That way we were getting an unfiltered view of both their ideas and of their rhetorical prowess. The Bedford series of books, which we had already read earlier in the class, contained excellent primary source examples, but the superb online American Presidency Project out of UC-Santa Barbara contained a wealth of searchable documents for students to explore ${ }^{18}$ Most of this work was done outside of class, but we met regularly to guide and advise students, keep them on track, and get updates. We gave them a dry-run in class for each debate so we could edit their content and so they could gain experience presenting.

For the class with twenty-two students, we employed similar assignments and set-up. We accommodated the larger number of students by having two debates on Economic Policy, two debates on Social Policy, and one debate on Foreign Policy. This allowed us to have five FDRs, five Reagans, and five moderators. The remaining students worked on media outreach and/or were expected to contribute extra time finding sources and preparing their presidents. Ultimately, we found no perfect way of assigning equal work, but we found that the more advanced students in the class had no concerns about fairness as they relished the opportunity to be center stage.

If this class were taught with either fewer or more students, we believe this model could be applied successfully by manipulating the number of debates and/or the expectations of the supporting students. While Westminster's small liberal arts environment proved conducive to this project, with some modifications it could easily be applied at a larger campus. Although larger universities are known for their 500 student lecture classes, most of these classes are also broken up into smaller discussion sections. The combination of a large lecture coupled with the small sections allows for both information foundations-about the foreign policy preferences of presidents, for example-to be laid out to all of the students in the class. The smaller sections allow for more specific instructions about debate formats, historical examples, and presidential speech patterns to be introduced. To be sure, such a setting would likely not allow for a debate series to occur over three distinct policy spaces, but having the debates take place in the discussion sections would allow all of the students in the class to play a role in a deeper dive into liberal and conservative thought in one policy space. This would also have the added benefit to graduate teaching assistants of offering them a place to practice their nontraditional pedagogy, which in turn could increase their job prospects.

While we were able to successfully inhabit Roosevelt and Reagan, it should be noted that similar structure with more concise policy spaces would also work, and may be more appropriate to some classes. Post-WWII or Vietnam War history classes, for example, could fashion a debate between Lyndon Johnson and Richard Nixon, or even Hubert Humphrey and George McGovern to highlight the political difficulties of both defending and ending a U.S. war in Vietnam. Additionally, state universities do have smaller seminar type classes for their upper-level majors. Our project can serve as a model for professors in this setting. Upper-level classes on the history of the U.S. political parties, U.S. diplomatic history, and other similar topics could provide spaces suitable for this topic.

In our classes, the debates went off without a hitch. We occupied the largest lecture hall on campus and attracted a small audience of mostly the students' friends. Moving to a more prominent environment also

\footnotetext{
18 “The American Presidency Project," https://www.presidency.ucsb.edu
} 
created a space something more akin to an actual debate stage. According to the Harvard School of Education's advice on role-playing in the classroom, creating a "real world" environment is an essential component to maximizing the effect of such an exercise. ${ }^{19}$ We projected images of the American flag on a large screen behind the students during the debate. Similarly, we requested that students dress professionally in their debates, although we appreciate that the socio-economic status of each student might not always facilitate this. One of the student's parents showed up in the second class. The local newspaper, the Fulton Sun, ran a front-page article on the event. ${ }^{20}$ Having prepared scripts clearly helped with the students' nervousness, but-having spent so long understanding the issues and absorbing past presidential debates-all seemed comfortable with responding to questions in the rebuttal section.

We equivocated as to whether we wanted to declare a winner of the debates. After all, the point of the class is to listen to the other side and empathize with their point of view. However, the students overwhelmingly wanted a vote at the end of the debates. Perhaps this gave them the necessary incentive to put in extra effort. We asked the students and audience members in attendance to vote via anonymous paper ballot on who they thought won the debates. This created some fascinating moments of high tension as the results were read. In the first class, Reagan won 2-1. In the second class, FDR won 3-2. We were curious to know why each president won.

We spent some time following the debates debriefing how and why each president was the most persuasive. We observed that presentation and rhetorical clarity plays an enormous role in influencing our students as to who won. We had observed this previously when students (of both classes) watched past presidential debates and tended to focus on who looked the most "presidential." Perhaps we are all guilty of this: When we think of the moments that we remember from past debates, it is Nixon sweating, Reagan's sunny quips, Bush looking at his watch, or Clinton's "feeling our pain," etc. One response to Al Gore’s sighing in the first presidential debate of 2000 was, "He sounded like a dick." The messenger seemed as important as the message. As such, the calmer, more prepared, and more relaxed students tended to win the debates. This observation could lead to a wider discussion with students about the importance of "likeability" in presidential candidates. But is also gave them a clear example of Neustadt's main thesis that presidents cannot dominate politics without the ability to persuade and maintain their legitimacy or prestige. More importantly, we wanted to know what, if anything, each student had learned about liberalism, conservatism, and rational political dialogue.

\section{Examining Students' Experiences and Feedback}

At the end of the first class, we erred by not collecting substantive feedback on how, or if, the students' perspectives on these issues had evolved. We did, at least, have meaningful discussions around these issues, and it was clear that the class had significantly increased their knowledge on both FDR and Reagan and on the nature of presidential power and persuasion. They all agreed that they had also broadened their understanding of, and empathy with, diverse political viewpoints. For the second iteration of the class, we wanted to be far more intentional in expanding on these points. For the students' final assignment, we required them to write substantive answers to the following questions:

- Would you consider yourself more conservative, liberal, or neutral/undecided before taking this class? (Optional if you do not want to answer)

- What were some of your conceptions about liberalism before taking the class?

- What were some of your conceptions about conservatism before taking the class?

- What did you know about FDR before taking this class? Any stereotypes? Myths?

- Did the class change your views on FDR in any way? If so, how?

\footnotetext{
19 “Want to Facilitate Role Playing in Your Class?" Harvard University, ABLConnect, https://ablconnect.harvard.edu/wantfacilitate-role-playing-your-class

${ }^{20}$ Helen Wilbers, "Students Channel Roosevelt, Reagan," Fulton Sun, May 2, 2019, https://www.fultonsun.com/news/local/ $\underline{\text { story } / 2019 / \text { may/02/students-channel-roosevelt-reagan/776873/ }}$
} 
- What did you know about Reagan before taking this class? Any stereotypes? Myths?

- Did the class change your views on Reagan in any way? If so, how?

- What books/assignments worked best for preparing you for expanding your knowledge on FDR/ Reagan? What worked least?

- Did this class expand your knowledge of the American Presidency? Explain why or why not.

- What did you learn about presidential speech/rhetoric/communication during this course?

- Did the debate format allow you to get to know each president, their leadership styles, and their policies more fully than from just readings? Explain why or why not.

- Did the class content and format give you a better understanding about American politics today?

- What are the main lessons you took away from this class? List three or four and explain your answers.

- What would you like to see done differently in future iterations of this class? (i.e. assignments, readings, group work)

- Did you work more / less / same as your other upper-level major courses?

- Is there anything that you would like to add that we have not asked you about? Be as honest as you like.

Because we required students to turn in these responses to complete the course, they were not anonymous. Therefore, we accepted that there is an inherent risk that they would write what they thought we wanted to hear. But having worked closely with them in this and several other classes, we encouraged them to be as honest as possible, and we are confident that they were.

We were very encouraged with the responses. Universally, every student noted that they had increased their content knowledge of FDR, Reagan, liberalism, conservatism, and the presidency. One student who had little background in political history noted,

I've learned most about, firstly, the central ideas flowing underneath both dominant ideologies present in America today. Second, I've learned a lot about the figureheads of those two ideologies, both about who they were, and what their ideals are. Armed with these lessons, I can confidently say that I understand American politics far better than I used to.

Another, who self-identified as a small-government conservative added, "Though I'm still extremely skeptical of the Executive, I now better understand its role and respect its necessity within our system." Most encouraging were the ways in which the course seems to have opened students' minds to new ways of political thinking.

The role-playing debate seems to have amplified this intellectual growth. Every student noted that the debates allowed them a far deeper learning experience than just analysis of texts. One stated, "The debates were probably my favorite parts of the class, and in my opinion did teach me more about my own assigned president than the readings on the specific subject to which I was assigned." Another added,

The debate was the single most enlightening assignment in this class that allowed me to learn more about the two Presidents. In order to truly debate, both for and against the two men, I had to deep dive into their time as President, including the victories and the criticisms. I was able to more thoroughly examine the issues that were assigned to me, and through those few questions I was able to extrapolate ideology, policy, and personality in a more personal and real way than simply reading about them.

While there is scope for further data collection and analysis in future iterations of this class, the early signs are encouraging. 
A key goal for the course was for students to empathize with and to understand the importance of bipartisanship and compromise. In our classroom discussions and assignment debriefs, this is an issue we stressed. We repeatedly asked students to analyze and reflect on why it is so important to achieve compromise and to acknowledge opposing viewpoints, otherwise we ran the risk of hardening the lines which divided the two sides. One of the questions we asked at the end of the course was whether students' opinions of either liberalism or conservatism had changed. One conservative student stated, "I believed that majority of liberals were just young people, who did not know what they were talking about, and followed this party because it was the cool thing to do. After this course I realized I was wrong, and I do have more respect for them." A student who identified as liberal claimed,

I learned to respect Reagan a lot more. For one, I learned why people respected him and hailed him as one of the greatest presidents. I also learned to respect conservatism a lot more. It is more than simply religion or racism and the true meaning of conservatism is overlooked due to radicals and/or my own not delving enough into the ideology of it.

Such acknowledgment of diverse viewpoints is a baseline for rational political dialogue and compromise. In future iterations of this course, however, we want to push students to express the need for bipartisan understanding further. We may make it a part of their final reflective essay to express fully how their acquired knowledge on FDR, Reagan, and the presidency can point to a more amicable future. We may also encourage students to present their ideas to the campus community or encourage them to write op-eds to school and local newspapers. Certainly, more data is needed, but we are encouraged by the initial signs.

\section{Conclusion}

Based on the formal and informal student feedback, we believe that teaching this class has allowed our students to explore how it is both possible and necessary to have rational and respectful political discourse. Both FDR and Reagan were great communicators and were able to articulate their visions for the United States in ways that seem lost in the current political milieu. We believe that the course demonstrated that both of these icons of liberalism and conservatism cared deeply for this nation, and that neither of the philosophies they espoused pose the kind of existential threat to society that their naysayers often opine. Contemporary politicians and political pundits would do well to heed their example.

Not everyone agrees with the policies enacted by FDR or Reagan; far from it. They had their detractors at the time and ever since. But they were able to persuade the electorate that both liberalism and conservatism can both serve the common good if understood and presented rationally. One can only speculate as to how their message might have held up in the current environment of social media and cable news scrutiny. But they had a style of leadership that, we believe, allows our students to appreciate the value of both liberalism and conservatism. Studying both presidents, emulating them, and ultimately becoming them in the classroom provided an opportunity for students to move beyond the negative stereotypes and vitriol that is such an unwelcome part of their political lives. 